\title{
Nualeus Animalium
}

\section{EDITORIAL}

Ética na pesquisa...

"Vivemos em uma época pós-tudo", onde todos carregam a verdade, a melhor solução, o que é novo e o que deve prevalecer sobre o quê e para quê se queira. A moda é contestar, a moda é ser sofisticado, a moda é ser cientifiques. Vai-se, ao longe, a necessidade do método, do clássico, do estabelecido, do ponto de partida.

A priori não existe mais.

Os fenômenos são criados a partir do e pelo sujeito, desprezando-se a coisa-em-si.

"Cadê a racionalidade?" perguntariam alguns. "Qual ética?" diriam outros. Mas, se perguntariam: "qual o método?", “qual procedimento?", “qual o instrumental?", “faz-se isto com ética?", "isto é bom?", "isto é certo?". E, nem se diga então: "o que é/seria o bom?”, “o que é/seria o certo?”, “o que é/seria o adequado”. Em suma: o homem é o centro de tudo/medida de todas as coisas + ausência de racionalidade instrumental $=$ fim das certezas (?).

O homem, no seu egocentrismo, coloca-se no centro de todas as coisas. Diz e não diz o que quer de tudo e mais um pouco, e além desse pouco. Foi o homem que criou os limites do universo através de postulados, e após descobertas se fala até em multiverso.

Há ciência natural, social, alográficas (música e teatro), autográficas (pintura e romance), não sendo possível utilizar um mesmo instrumental para elas, pois há epistemologia e metodologia diversas. Há modos de compreensão e reprodução que não são correspondentes. Não é possível criar um instrumento universal para todas as ciências, $v . g^{l}$., o Círculo de Viena. Da mesma forma que resta comprometida a aplicação de postulados de culturas diferentes, $v . g$.,

${ }^{1}$ Notas do Editor: Do latim verbi gratia, que significa por exemplo. 
ocidente versus oriente, common law versus civil law ${ }^{2}$. Também, como contestar a função da base dogmática do Idjmâ $\hat{a}^{3}$ ou os livros de figh na tentativa de inserir/aplicar tais dogmas nos países romano-germânicos? Há sim problemas até na racionalidade no reconhecimento do diálogo das fontes que (in)formam determinados sistemas, comprometendo o próprio fluxo e acoplamento. Daí que a falência e a carência de um instrumento universal implicam a cada ciência a busca pelos seus aparelhos, procedimentos, dogmas, linguagens, ou seja, buscar suas ferramentas científicas adequadas. Necessita-se, portanto, haver uma identidade da pesquisa. Não se pode separar cientificidade de eticidade, embora sejam questões distintas. Trocando em miúdos: posso aplicar regras do futebol no basquetebol?

Infere-se que, com as ferramentas científicas adequadas, com um instrumental estabelecido a priori pela comunidade científica, a pesquisa torna-se, ao menos convencionalmente naquele dado momento histórico, ao mesmo tempo em que racional, ética. Não basta o investigador ser sincero com "o fazer" a pesquisa, mas também preocupar-se com o "fazer com o quê", "fazer como", "fazer para quê", "fazer utilizando o quê". Ao tratar o objeto de investigação deve-se ter necessariamente uma perspectiva ética, e, em se tratando de seres humanos, bioética.

Com um instrumental científico adequado a cada área, portanto, racionalmente há possibilidade de se evitar comportamento ético com valor negativo, nocivo. Para isso, o homem pode se colocar no centro, com escolha e utilização de instrumentos, na construção de pesquisas com ética.

Cabe a esta instituição educacional - como em todas as outras -, que é fomentadora de pesquisas, e especialmente aos cientistas, velar pela ética na pesquisa, buscando um instrumental adequado, ou que se descubra algum, e que o mesmo seja utilizado com parâmetros racionais, controláveis e éticos. Tijolo com tijolo num desenho lógico...

João Josué Walmor de Mendonça - Pós-Graduado em Direito Público. Membro do Comitê de Ética em Pesquisa da FE/FFCL - CEP, conforme Res. 196/96, do Conselho Nacional de Saúde. Coordenador da Comissão de Direitos e Prerrogativas dos Advogados, 70 ${ }^{\text {a }}$ Subsecção da OABSP, Ituverava-SP. Membro da Comissão de Ética e Disciplina, Secção de São Paulo, 70ª Subsecção, Ituverava-SP, participante como Instrutor. Advogado.

\footnotetext{
${ }^{2}$ Do Direito comum contra a Lei Civil

${ }^{3}$ Acordo unânime da comunidade muçulmana, baseado em duas declarações de Maomé: "o que os muçulmanos considerarem justo é justo para Deus" e "a minha comunidade nunca chegará a acordo sobre um erro".
} 